\title{
EFFECT OF ANTIOXIDANTS ON POLYUNSATURATED FATTY ACIDS - REVIEW
}

\author{
Ancuța Elena Prisacaru ${ }^{\varpi}$ \\ Faculty of Food Engineering, Stefan cel Mare University of Suceava \\ Universității Street no 13, 720229 Suceava, Romania
}

\begin{abstract}
This paper aims to review the available literature data and provide an overview regarding the efficiency of antioxidants to prevent peroxidation of polyunsaturated fatty acids. Lipid peroxidation is a serious problem that often leads to a loss of shelf-life, reduced consumer acceptability, poorer functionality, lower nutritional value, and poorer safety. It represents an oxidative degradation of polyunsaturated fatty acids incorporated in cell membrane lipids or in lipoproteins, but also in vegetables and food oils rich in PUFA n-3. It is a complex process that leads to the production of numerous highly reactive metabolites with consequences for food preservation and for the development of various diseases. The targets of lipid oxidation are polyunsaturated fatty acids. Lipid peroxidation can proceed by means of two different reactions that lead to the formation of hydroperoxides as primary products. Hydroperoxides decompose rapidly to give many secondary products, such as lipid free radicals, which contribute to increased oxidation of other molecules, such as proteins, nucleic acids and other lipids. Lipid peroxidation is a major problem for the food industry, as well as for human health, since it is associated with many diseases. The use of antioxidants reduces oxidative damage.
\end{abstract}

Key words: lipid peroxidation, antioxidants, polyunsaturated fatty acids

\section{INTRODUCTION}

The intake of polyunsaturated fatty acids like n-3 (PUFA n-3), with anti-inflammatory characteristics, has a favorable effect on the prevention of some medical conditions, such as cardiovascular diseases (Schacky and Harris, 2007) and some chronic illnesses like cancer (Simopoulos, 2008). However, feeding habits are characterized by a low intake of polyunsaturated fatty acids n-3 (especially those with short chain) and an excessive value of the report PUFA n-6/PUFA n-3 (Simopoulos, 2008).

Polyunsaturated fatty acids are indispensable and necessary for cellular functioning but they are not synthesized by the human or animal organism and must be introduced into the body through alimentation.
Most foods are richer in PUFA n-6 (dairy, eggs, beef and pork products) than PUFA n-3 (fish and other sea foods, nuts, leafy vegetables). PUFA are very sensitive to lipid peroxidation due to their structure. This reaction is initiated by oxygen-free radicals action that attack and degrade PUFAs determining the appearance of some toxic and very reactive molecules (peroxide products). An increase in the PUFA n-3 content of food products offers protection against peroxidation until consumption and plays an important role in human health assurance, offering economic benefits but requiring the use of antioxidants (Schacky and Harris, 2007). Various antioxidants prevent or slow the cellular peroxidation process. They can have industrial 
origin, having been obtained through chemical synthesis (vitamin E), or natural origin (vegetal extracts). Vitamin E, the most utilized antioxidant, exhibits some disadvantages regarding the efficiency and a pro-oxidant risk in the case of some high doses. Research was done and a mixture of a vegetable extract (rich in natural polyphenols) and vitamin $\mathrm{E}$ was obtained. This mixture presented a high capacity for protection against lipid peroxidation on animals (mice), thus the alimentation being enriched in PUFA's n-3 (Gladine, 2006).

\section{LIPID PEROXIDATION PROCESS}

Oxidant stress is a type of aggression on the part of some cellular compounds that determines an imbalance between the antioxidant defense system and the production of nitrates and oxygenated compounds. This imbalance may have different origins, such as endogenous overproduction of prooxidant agents of inflammatory origin, a nutritional deficit in antioxidants or even exposure to prooxidant factors from the environment. This imbalance between the defense system and the free radical generation one trains the appearance of structural lesions at the level of organism cells. This determines, at molecular level, proteins and ADN degradation, sugar modification, altering the integrity of cellular membranes by inducing lipid peroxidation (Favier, 1997).

Lipid peroxidation represents an oxidative degradation of polyunsaturated fatty acids incorporated in cell membrane lipids or in lipoproteins, but also in vegetables and food oils rich in PUFA n-3 (Cillard and Cillard, 2006).

In humans and animals, lipid peroxidation is considered physiological when its intensity is controlled through the action of prooxidant enzymes like prostaglandin synthetase, tromboxan synthetase and lipoxygenase. This peroxidation induced by enzymes is indispensable to animal or human organisms favoring the formation of prostaglandins and leukotrienes. It stimulates smooth muscle contractions and the biosynthesis of steroid hormones. It differentiates from non-enzymatic lipid or spontaneous peroxidation, which is often fatal for the effective functioning of the human organism, contributing to cellular aging and toxic metabolite production (Pré, 1991).
Spontaneous lipid peroxidation is influenced by reactive oxygen species (ROS) and PUFAs. Free radicals are defined as atoms or molecules that contain an unpaired electron (free). This property explains their high reactivity and ability to react with some molecules (lipids, proteins, DNA) and produce chain reactions (Favier, 1997).

Free radical reactivity is very variable depending on the nature of the radical. Among the radicals formed in living beings, the superoxide anion radical $\left(\mathrm{O}_{2}^{-}\right)$and nitric oxide $\left(\mathrm{NO}^{-}\right)$are not particularly reactive, but are precursors that can be activated by other species more reactive. On the other hand, weak reactivity of these two radicals allows the organism to use them as mediators that regulate biological functions like capillary vasodilatation. Peroxyl (ROO') and hydroxyl ( $\left.\mathrm{HO}^{\circ}\right)$ radicals are extremely reactive. There are other derivate species called "reactive oxygen species" (ROS), like hydrogen peroxide $\left(\mathrm{H}_{2} \mathrm{O}_{2}\right)$ or nitroperoxid $(\mathrm{ONOOH})$, which are also reactive (Winterbourn, 2008).

Fatty acids with a long chain are made from a linear chain of carbon atoms (12-22 atoms) and a methyl group $\left(\mathrm{CH}_{3}\right)$ at one extremity and a carboxyl group $(-\mathrm{COOH})$ at the other. Fatty acids can have one or more ethylenic double bonds (up to 6) along the hydrocarbon chains and according to their number, we can talk about saturated fatty acids (they don't have any double bonds), monounsaturated fatty acids (one double bond) or polyunsaturated fatty acids (they have more double bonds). Fatty acids that have two conjugated double bonds are present, in general, in fats resulted from industrial hydrogenation of vegetal oils (margarine) or in ruminant lipids (Chardigny and Malpuech-Brugere, 2007) and especially in the lipids of products obtained from them, such as milk (Chilliard et al., 2001) and meat (Bauchart et al., 2008).

\section{LIPID PEROXIDATION REACTIONS}

Polyunsaturated fatty acids are the preferred targets for the reactive oxygen species (ROS) due to the presence of numerous bis-allylic hydrogen atoms which are easily oxidized. Fatty acids rich in double bonds are peroxidizable, meaning that they are degradable by a non-enzymatic oxidant precursor harmful to the cell. The oxidation of polyunsaturated fatty acids takes 
place in three stages: initiation, propagation and termination (Pré, 1991).

Peroxidation mechanism is initiated when a reactive species of oxygen bonds a hydrogen atom from a methylen group $\left(-\mathrm{CH}_{2}-\right)$ to a polyunsaturated fatty acid. Hydroxyl radical $\mathrm{HO}^{\circ}$ is one of the most efficient initiators. The result of this initiation phase is the formation of an alkyl group ( $\mathrm{R}^{*}$ ) or a fatty acid and this instability will rapidly induce the formation of a conjugated diene from the remaining electrons, characterized by the presence of two double bonds conjugated (Winterbourn, 2008).

Propagation phase assumes the combination of dienil radical ( $(\mathrm{R})$ with oxygen forming peroxyl radical (ROO*). Peroxyl radicals can react with an adjacent lipid molecule $\left(\mathrm{R}^{\cdot} \mathrm{H}\right)$, engaging the formation of a hydroperoxide $(\mathrm{ROOH})$ and a new alkyl radical $\left(\mathrm{R}^{*}\right)$, ensuring the propagation of the reaction. It is widely accepted that every alkyl radical can be at the origin of some hydroperoxide molecules before the termination phase begins. Hydroperoxides are very unstable and decompose spontaneously in the presence of ionized forms of transition metals $(\mathrm{Fe}, \mathrm{Cu})$ with a hemin structure (hem, met hemoglobin, citocromos). This is a complex process that involves the formation of alkoxy radicals (RO'), peroxyl (ROO') and different species called "cut" (split) (aldehydes and acids) by breaking the covalent bonds. The terminal phase involves the formation of compounds through the combination of radicals. An $\mathrm{R}^{\cdot}$ radical reacts with another free radical (ROO') or ( $\left.\mathrm{R}^{*}\right)$, allowing the neutralization of free radicals, and determining the lipid peroxidation chain termination (Pré, 1991).

\section{LIPID PEROXIDATION INTENSITY}

Oxidant stress determines an imbalance between the antioxidant defense system and the production of oxygen reactive species. Thus to assess the intensity of lipid peroxidation, it is more practical to track the results of this imbalance than to determine the lesions which occur and especially to evaluate lipid oxidation products (Favier, 1997).

Several biomarkers have been proposed to evaluate the intensity and the amplitude of lipid peroxidation, which differ by their specificity and sensitivity. None of these biomarkers are able to provide an exhaustive view with regard to the in vivo lipid peroxidation process, determining the simultaneous involvement of several biomarkers. In the case of hydroxyalkane, due to its effective metabolism, the measurement is based only on the evaluation of free 4-HNE concentrations or of the adducts to the proteins or glutathione, estimating in this way the real intensity of lipid peroxidation in specific pathologic conditions. Thus, the free and conjugated forms must be measured in parallel to appreciate the intensity of PUFA n-3 and n- 6 peroxidation (Guichardant and Lagarde, 2009). Different measurement techniques have been developed (Table 1).

The advantage of evaluating different 4-HNE and 4-HHE forms is given by the fact that these two markers are simultaneous determined in a single analysis. Regarding lipid peroxidation intensity evaluation in food products, MDA detection is largely used. 4-HNE assessment in this kind of matrix has been the objective of different studies on fish, pig and beef meat (Munasinghe et al., 2003a; Munasinghe et al., 2003b; Munasinghe et al., 2005; Munasinghe et al., 2006; Sakai and Kawahara, 2009; Zanardi et al., 2002). It is conceivable that this marker can be used in food quality assessment (Zarkovic, 2003).

Oxygen free radicals are the source and are implicated in the control of a large variety of oxidationreduction reactions indispensable for life and growth. Any kind of stress increases their flow, depletes the body's reserves in protective compounds that neutralize them (antioxidants like vitamin $\mathrm{C}$ and $\mathrm{E}$ and glutathione) and thus increase the corresponding needs of the organism. This stress may lead to alterations in cell structures (Aurousseau, 2002).

\section{BIOLOGICAL EFFECTS OF LIPOPEROXIDATION}

Most of the end products of lipid peroxidation react with proteins, lipids and DNA. Aldehyde compounds like 4-HNE, 4-HHE, MDA and acrolein are very reactive and bond directly with thiol groups of residue proteins and peptides containing cysteine, histidine and lysine to form stable products (Esterbauer et al., 1991).

These products (considered pathological) are determined in different tissues and blood, causing oxidative damage that causes diseases (Niki, 2009).

The attack of the products resulting from lipid peroxidation on the protein residues can deactivate various 
Prisacaru, A. E. (2016). Effect of antioxidants on polyunsaturated fatty acids - review. Acta Sci. Pol. Technol. Aliment., 15(2), 121-129. DOI: 10.17306/J.AFS.2016.2.12

Table 1. Methods for detecting and determining HNE (Poli et al., 2008)

\begin{tabular}{|c|c|c|c|}
\hline $\begin{array}{l}\text { Compound } \\
\text { detected }\end{array}$ & Method applied & Material analyzed & References \\
\hline Free HNE & $\begin{array}{l}\text { - HPLC reverse phase } \\
\text { - ELISA } \\
\text { - MS way EI (DHNd11 intern standard) } \\
\text { - Micro extraction in solid phase, } \\
\text { HPLC } \\
\text { - MS way EI } \\
\text { - Extraction in solid phase, } \\
\text { HPLC-MS/MS } \\
\text { - Fluor immunoassay } \\
\text { - LC-MS/MS } \\
\text { - LC-APCI-MS }\end{array}$ & $\begin{array}{l}\text { - LDL oxidized } \\
\text { - Extracts of T human cells } \\
\text { - Oxidized oils, pig liver } \\
\text { - Nuclei from sarcoma cells } \\
\text { - Meat } \\
\text { - Serum and plasma from rats } \\
\text { - Condensed from breath } \\
\text { - Oxidized linoleic acid }\end{array}$ & $\begin{array}{l}\text { Esterbauer and Cheeseman, } \\
1990 \\
\text { Uchida et al., } 1995 \\
\text { Uchida et al., } 2000 \\
\text { Calonghi et al., } 2002 \\
\text { Zanardi et al., } 2002 \\
\text { Kimura et al., } 2005 \\
\text { Corradi et al., } 2004 \\
\text { Lee et al., 2005 }\end{array}$ \\
\hline $\begin{array}{l}\text { GSH-HNE } \\
\text { Adducts }\end{array}$ & $\begin{array}{l}\text { - HPLC } \\
\text { - HPLC } \\
\text { - HPLC-MS/MS way EI }\end{array}$ & $\begin{array}{l}\text { - Rats in vivo } \\
\text { - Kidney cells and rat bile }\end{array}$ & Ji et al., 2002 \\
\hline DHN-MA & $-\mathrm{MS}$ & - Human urine & Gueraud et al., 2006 \\
\hline $\begin{array}{l}\text { Carnosine } \\
\text { adducts }\end{array}$ & - Characterization by MS/MS mode EI & - Skeletal muscle & Aldini et al., 2002 \\
\hline $\begin{array}{l}\text { Adducts } \\
\text { to protein }\end{array}$ & $\begin{array}{l}\text { - Anti-HNE-LDL acid polyclonal } \\
\text { - Polyclonal acid (Histidine adducts) } \\
\text { - Monoclonal acid (Histidine adducts) } \\
\text { - Polyclonal acid } \\
\text { - Immunoprecipitation } \\
\text { - Immunoprecipitation } \\
\text { - Western blotting } \\
\text { - Immunofluorescence imaging } \\
\text { - Fluorometry } \\
\text { - MS/MS wayEI } \\
\text { - MS/MS way EI } \\
\text { - MS way EI after immunoaffinity } \\
\text { enrichment-MALDI-MS } \\
\text { - MALDI-MS } \\
\text { - MALDI-MS } \\
\text { - Dimensional eletroforeze/Western } \\
\text { blotting }\end{array}$ & $\begin{array}{l}\text { - LDL oxidized with } \mathrm{Cu}^{2+} \\
\text { - Rats hepatocytes } \\
\text { - Different cell types } \\
\text { - Human brain } \\
\text { - Human cord } \\
\text { - Mitochondrial isocitrate } \\
\text { dehydrogenase } \\
\text { - Rat heart } \\
\text { - Sections of rat hearts } \\
\text { - Human plasma } \\
\text { - Chain B oxidized by insulin } \\
\text { - LDL oxidized } \\
\text { - Apomyoglobin } \\
\text { - Peptides } \\
\text { - DNPH matrix } \\
\text { - Cytochrome c } \\
\text { - Lymphocytes }\end{array}$ & $\begin{array}{l}\text { Chen et al., } 1992 \\
\text { Uchida et al., } 1993 \\
\text { Borovic et al., } 2006 \\
\text { Montine et al., } 1997 \\
\text { Pedersen et al., } 1998 \\
\text { Benderdour et al., } 2003 \\
\text { Eaton et al., } 1998 \\
\text { Eaton et al., } 1998 \\
\text { Massarenti et al., } 2004 \\
\text { Fenaille et al., } 2003 \\
\text { Sangvanich et al., } 2003 \\
\text { Fenaille et al., } 2003 \\
\\
\text { Doorn and Petersen, } 2003 \\
\text { Fenaille et al., } 2004 \\
\text { Aldini et al., 2006 } \\
\text { Poggioli et al., } 2004\end{array}$ \\
\hline
\end{tabular}

cell enzymes and may alter the conformation of structural proteins. The consequences are as follows:

- An attack on the circulating lipids leads to oxidized lipoproteins with low density formation, whose final consequences are strokes.

- The attack on the membrane phospholipids with influences on transporters, receptors and transmitting signals.
Aldehydes also have a mutagenic effect and form DNA-based compounds such as propanol or ethanol (Favier, 2003).

In the case of dairy animals, lipid peroxidation can lead to an increased susceptibility to infections or pathological inflammations and also impaired liver function and reproductive performance. In meat animals performance may be reduced and animal growth 
and feed transformation efficacy may be affected (Aurousseau, 2002).

The role of antioxidants on health and immunity conservation has been studied in the case of ruminants (Spears and Weiss, 2008). The relation between oxidative damage and vitamin $\mathrm{E}$ concentration in blood, liver and milk was evaluated in cows receiving or not receiving a supplement of vitamin $E$ in their daily rations. A poor plasma MDA concentration in cows that had received a vitamin E supplement for two weeks after calving clearly showed that this vitamin plays a positive role in the subsequent recovery of an animal subjected to oxidative stress due to parturition. Vita$\min \mathrm{E}$ is an antioxidant able to limit lipid peroxidation (Bouwstra et al., 2008).

There is a negative correlation between plasma antioxidant potential and common pathologies, a daily intake of vitamin E for 4 weeks of gestation (1000 UI/ animal/day) is recommended to reduce the risk of placenta retention (Miller et al., 1993). Vitamin E doses must be rationed because a high intake may have negative consequences, such as increased mortality. This has been demonstrated in people who have received a dietary supplement of vitamin $\mathrm{E}$ of to $400 \mathrm{UI} /$ day or greater (Miller et al., 2005).

\section{PRO- AND ANTIOXIDANT SYSTEMS}

In the body at rest, the mitochondria are one of the sites of free oxygen radical production, in particular superoxide anion $\left(\mathrm{O}_{2}^{0-}\right)$. This product is a natural source of free radicals likely to be stimulated by food and environmental variations in the absence of pathologies or any other pronounced imbalance (Aurousseau, 2002).

Electrons are involved in carrying oxygen metabolism in the mitochondrial respiratory chain and lead to the production of superoxide anions $\left(\mathrm{O}_{2}^{0-}\right)$. About $2 \%$ of the oxygen consumed in the mitochondria is converted to superoxide radical (Gladine, 2006).

Starting with the superoxide anion $\left(\mathrm{O}_{2}^{-}\right)$, a large variety of other oxygen free radicals are formed. These are known as "secondary". Two molecules of superoxide can associate to form hydrogen peroxide $\left(\mathrm{H}_{2} \mathrm{O}_{2}\right)$. Hydroxyl radical production (HO') is initiated starting from the hydrogen peroxide reaction in the presence of metal cations $\left(\mathrm{Fe}^{2+}\right.$ or $\mathrm{Cu}^{2+} ;$ Fenton reaction). Nitric oxide $\left(\mathrm{NO}^{*}\right)$ can react with superoxide anion radical
$\left(\mathrm{O}_{2}^{-}\right)$forming a highly toxic peroxynitrite (-OONO) (Halliwell and Gutteridge, 1984):

- reaction 1: $\mathrm{O}_{2}^{-}+\mathrm{O}_{2}^{-}+2 \mathrm{H}^{+} \rightarrow \mathrm{H}_{2} \mathrm{O}_{2}+\mathrm{O}_{2}$

- reaction $2: \mathrm{H}_{2} \mathrm{O}_{2}+\mathrm{Fe}^{2+} \rightarrow \mathrm{HO}^{\cdot}+\mathrm{Fe}^{3+}+\mathrm{HO}$ (Fenton reaction)

- reaction 3: $\mathrm{NO}^{*}+\mathrm{O}_{2}^{-} \rightarrow-$ OONO.

An antioxidant can be defined as a substance that delays or inhibits oxidation of a substrate (Halliwell and Gutteridge, 1984).

To defend itself against attacks from radicals, the body has two great systems of protection: detoxification enzymes and intra- and extracellular nonenzymatic antioxidants that occur at different levels of the lipid peroxidation chain reactions. Endogenous antioxidants (enzymatic or non-enzymatic) and those from food (lipophilic or hydrophilic) are classified into several categories depending on their mode of action. Antioxidants acting previous to lipid peroxidation prevent its initiation. Transition metal chelators are able, by forming complexes with metals $(\mathrm{Cu}, \mathrm{Fe})$, to initiate lipid peroxidation catalysis (Frankel, 2005). This mechanism of action still has a minor influence in terms of inhibition of lipid peroxidation in comparison with its anti-radical activity by capturing active oxygen compounds (Van Acker et al., 1998).

Transition metal chelators are mainly proteins (transferrin, ferritin, lactalbumins) able to seize Fe, ceruloplasmin and albumin able to form compounds with $\mathrm{Cu}$. Polyphosphates, ethylene diamine tetraacetic, citric and phenolic acids and flavonoids are present in extracellular or intracellular aqueous environments and known for their ability to chelate transition metals (Laguerre et al., 2007).

The sensors of reactive oxygen species are able to prevent oxidation. In this case, carotenoids, with lipophilic properties, are considered to be the most efficient molecules for singlet oxygen capture $\left({ }^{\circ} \mathrm{O}_{2}\right)$ and $\mathrm{ROO}^{*}$ and $\mathrm{R}^{*}$ radicals. They are present in vegetable pigments, like carotene (lycopene, $\beta$-carotene) or xanthophylls (astaxanthin, lutein). Their conversion is possible in the liver and enterocytes in which the obtained retinol (vitamin A) also possesses antioxidant properties.

There are other compounds that capture the singlet oxygen, tocopherols and tocotrienols namely, grouped under the common name of vitamin E. They 
are present naturally in wheat germ and vegetable oils, but can be synthesized chemically as $\alpha$-tocopherols to meet human needs in terms of antioxidants. Carotenoids and tocopherols contribute in the same way to the protection of tissues against the harmful effects of singlet oxygen, especially because in vivo tocopherols are around 30 times more abundant than $\beta$-carotene (Laguerre et al., 2007).

Superoxide anion present in the aqueous phase can be captured by vitamin C (hydrophilic), which is abundant in citrus fruits and vegetables, and also is able to capture peroxynitrite (-OONO). Polyphenols, mainly with hydrophilic properties, have an ideal chemical structure for the uptake of reactive oxygen species, easily releasing a hydrogen atom from a hydroxyl group (HO'). The antioxidant potential of certain polyphenols could easily exceed that of vitamin $\mathrm{E}$ (Vertuani et al., 2004).

Numerous other molecules are able to directly neutralize the ERO, such as glutathione (GS) and thiol, the latter being present mostly intracellular or only in a reduced form. Thiol is able to neutralize hydroxyl (HO), peroxyl (ROO') and alkoxy (RO') radicals, releasing a hydrogen atom from its sulfhydryl group (-SH). Peroxyl radical (ROO') is captured by bilirubin, uric acid and coenzyme Q10 localized at the level of mitochondria membrane and lipoic acid, cofactor involved in Krebs cycle. Hydroxyl radicals (HO') are also captured by uric and lipoic acids. Albumin action is important as long as the main supplier of thiol groups is plasma. Glutathione gives it the power of reduction (Gladine, 2006).

\section{DETOXIFYING ERO}

Detoxification in ERO is an important enzymatic pathway in preventing lipid peroxidation. Superoxide dismutase (SOD) located in the cytoplasm, mitochondria or in the extracellular environment is a metalloenzyme catalyst of superoxide radicals dismutation to hydrogen peroxide $\left(\mathrm{H}_{2} \mathrm{O}_{2}\right)$ and oxygen:

$$
2 \mathrm{O}_{2}^{-}+2 \mathrm{H}^{+} \rightarrow \mathrm{H}_{2} \mathrm{O}_{2}+\mathrm{O}_{2}
$$

Catalase is a hemin enzyme, located in intracellular peroxisome that converts hydrogen peroxide into water and molecular oxygen (Halliwell and Gutteridge, 1984):

$$
2 \mathrm{H}_{2} \mathrm{O}_{2} \rightarrow \mathrm{H}_{2} \mathrm{O}+\mathrm{O}_{2}
$$

Glutathione peroxidase (GP), present at the cytoplasmic and mitochondrial level, is a metal-selenium enzyme which detoxifies hydrogen peroxide and lipid hydroxy peroxides, linking hydroxy peroxide reduction with the glutathione oxidation (Halliwell and Gutteridge, 1984):

$$
\begin{gathered}
\mathrm{ROOH}+2 \mathrm{GSH} \rightarrow \mathrm{ROH}+\mathrm{H}_{2} \mathrm{O}+\mathrm{GSSH} \\
\mathrm{H}_{2} \mathrm{O}_{2}+2 \mathrm{GSH} \rightarrow 2 \mathrm{H}_{2} \mathrm{O}+\mathrm{GSSH}
\end{gathered}
$$

Antioxidants that act after the initiation of a lipid peroxidation chain limit its propagation. These oxides, called "chain terminators" lose the hydrogen radical benefit to peroxy radicals (ROO') formed during lipid peroxidation chain propagation (Halliwell and Gutteridge, 1984):

$$
\mathrm{A}-\mathrm{H}+\mathrm{ROO}^{*} \rightarrow \mathrm{A}^{\circ}+\mathrm{ROOH}
$$

The first antioxidants involved are phenolic compounds, mono- or polyhydric (tocopherols, tocotrienols, flavonoids, phenolic acids and alcohols) with different substituents located in one or more aromatic cycles. These compounds are able to stabilize unpaired electrons through relocation. As vitamin E has a hydrophilic and hydrophobic end, it easily releases the hydrogen atom located at the hydrophilic part. A tocoferoxyl radical thus formed possess the ability to stabilize a single electron by resonance.

In vivo regeneration system allows the control of these types of radical reduction. Vitamin $\mathrm{E}$ is the antioxidant that destroys lipid peroxidation chain. Vita$\min \mathrm{C}$ is involved in tocoferoxyl radical regeneration. Polyphenols (flavonoids) may have equally the same action in vitamin E regeneration (Leger, 2006).

\section{CONCLUSION}

In living beings, lipid peroxidation mechanism and its regulation is related to the body. The use of antioxidants reduces oxidative damage. Lipid peroxidation is a complex process that leads to the production of numerous highly reactive metabolites. These compounds are involved in various human and animal diseases. Lipid peroxidation is a phenomenon that takes place in vivo and in vitro after the same mechanism. Molecular oxygen is not very reactive and it combines with fatty 
acids only after the initiation phase induced by free radicals. The primary products resulting from fatty acids' oxidation are peroxides that break down rapidly, giving numerous decomposition products that damage other molecules like proteins, nucleic acids and other lipids. The consequences of lipid peroxidation are a major problem in the food industry and because of this, the utilization of antioxidants is used for preventing aliments and preserving human health.

\section{ACKNOWLEDGMENTS}

The authors are very grateful to the anonymous referees for their valuable comments.

\section{REFERENCES}

Aldini, G., Carini, M., Beretta, G., Bradamante, S., Facino, R. B. (2002). Carnosine is a quencher of 4-hydroxynonenal: though what is themechanism of reaction? Biochem. Biophys. Res. Commun., 298, 699-706. DOI: $10.1016 / \mathrm{s} 0006-291 \times(02) 02545-7$

Aldini, G., Dalle-Donne, I., Colombo, R., Maffei Facino, R., Milzani, A., Carini, M. (2006). Lipoxidation-derived reactive carbonyl species as potential drug targets in preventing protein carbonylation and related cellular dysfunction. Chem. Med. Chem., 1, 1045-1058. DOI: 10.1002/cmdc. 200600075

Aurousseau, B. (2002). Oxygen radicals in farm animals. Physiological effects and consequences on animal products. INRA Prod. Anim., 15(1), 67-82.

Bauchart, D., Chantelot, F., Gandemer, G. (2008). Nutritional quality of beef and bovine offal: Recent results for the main nutrients. Cahiers Nutr. Dietet., 43 (Suppl. 1), 1S29-1S39.

Borovic, S., Rabuzin, F., Waeg, G., Zarkovic, N. (2006). Enzyme-linked immunosorbent assay for 4-HNE-histidine conjugates. Free Radic. Res., 40, 809-820. DOI: 10.1080/10715760600693422

Bouwstra, R. J., Goselink, R. M. A., Dobbelaar, P., Nielen, M., Newbold, J. R., Van Werven T. (2008). The relationship between oxidative damage and vitamin $\mathrm{E}$ concentration in blood, milk, and liver tissue from vitamin E supplemented and nonsupplemented periparturient heifers. J. Dairy Sci., 91(3), 977-987. DOI: 10.3168/ jds.2007-0596

Benderdour, M., Charron, G., Deblois, D., Comte, B., Des Rosiers, C. (2003). Cardiac mitochondrial NADP ${ }_{-}^{+}$ -isocitrate dehydrogenase is inactivated through 4-hy- droxynonenal adduct formation: An event that precedes hypertrophy development. J. Biol. Chem., 278, 4515445159. DOI: 10.1074/jbc.m306285200

Calonghi, N., Boga, C., Cappadone, C., Pagnotta, E., Bertucci, C., Fiori, J., Masotti, L. (2002). Cytotoxic and cytostatic effects induced by 4-hydroxynonenal in human osteosarcoma cells. Biochem. Biophys. Res. Commun., 293(5), 1502-1507. DOI: 10.1016/s0006$291 x(02) 00397-2$

Chardigny, J. M., Malpuech-Brugere, C. (2007). Trans and conjugated fatty acids: origins and nutritional effects. Nutr. Cliniq. Métabol., 21, 46-51.

Chen, T., Bunting, M., Karim, F. D., Thummel, C. S. (1992). Isolation and characterization of five Drosophila genes that encode an ets-related DNA binding domain. Dev. Biol., 151, 176-191. DOI: 10.1016/00121606(92)90225-6

Chilliard, Y., Ferlay, A., Doreau, M. (2001). Effect of different types of forages, animal fat or marine oils in cow's diet on milk fat secretion and composition, especially conjugated linoleic acid (Cla) and polyunsaturated fatty acids. Livest. Prod. Sci., 70(1-2), 31-48. DOI: 10.1016/ s0301-6226(01)00196-8

Cillard, J., Cillard, P. (2006). Mechanism of lipid peroxidation and antioxidation. Ocl. Oleagineux Corps gras Lipides, 24-29. DOI: 10.1051/ocl.2006.6666

Corradi, N., Kuhn, G., Sanders, I. R. (2004). Monophyly of $\beta$-tubulin and $\mathrm{H}^{+}$-ATPase gene variants in Glomus intraradices: consequences for molecular evolutionary studies of AM fungal genes. Fung. Genet. Biol., 41, 262-273. DOI: 10.1016/j.fgb.2003.11.001

Doorn, J. A., Petersen, D. R. (2003). Covalent adduction of nucleo-philic amino acids by 4-hydroxynonenal and 4-oxononenal. Chem. Bio. Interact., 143/144, 93-100. DOI: 10.1016/s0009-2797(02)00178-3

Eaton, S. B., Eaton, S. B., Sinclair, A. (1998). Dietary intake of long chain fatty acids during the palaeolithic. The return of omega-3 fatty acids to the food supply. I: Landbased animal products and their health effects. World Rev. Nut. Diet., 83, 12-23.

Esterbauer, H., Cheeseman, K. H. (1990). Determination of aldehydic lipid peroxidation products: malonaldehyde and 4-hydroxynoneal. Meth. Enzym., 186, 407-421. DOI: 10.1016/0076-6879(90)86134-h

Esterbauer, H., Schaur, R. J., Zollner, H. (1991). Chemistry and biochemistry of 4-hydroxynonenal, malondialdehyde and related aldehydes. Free Rad. Biol. Med., 11(1), 81-128. DOI: 10.1016/0891-5849(91)90192-6

Favier, A. (1997). The oxidative stress: Interest of its monitoring in clinical chemistry and problems of the choice 
of an appropriate parameter. Ann. Biol. Clin., 55(1), 9-16.

Favier, A. (2003). Oxidant stress: conceptual and experimental in understanding the diseases mechanism and therapeutic potential. L'actualité Chimiq., 269/270, $108-115$.

Fenaille, F. P., Visani, R., Fumeaux, C., Milo, C., Guy, P. A. (2003). Comparison of mass spectrometry-based electronic nose and solid phase microextraction gas chromatography- mass spectrometry technique to assess infant formula oxidation. J. Agric. Food Chem., 51, 2790-2796. DOI: 10.1021/jf026131w

Fenaille, F., Morgan, F., Parisod, V., Tabet, J. T., Guy, P. A. (2004). Solid-state glyxation of beta-lactoglobulin by lactose and galactose: localization of the modified amino acids using mass spectrometrie techniques. J. Mass Spectr., 39, 16-28. DOI: 10.1002/jms.539

Frankel, E. N. (2005). Lipid oxidation. The Oily Press, 470.

Gladine, G. (2006). Interest of vegetal extracts rich in polyphenols in the prevention of lipid peroxidation at rat and sheep receiving dairy supplements of n-3 PUFA. Thèse. Université d'Auvergne, Clermont-Ferrand.

Gueraud, F., Peiro, G., Bernard, H., Alary, J., Créminon, C., Debrauwer, L., ..., Bories, G. (2006). Enzyme immunoassay for a urinary metabolite of hydroxynonenal as a marker of lipid peroxidation. Free Radic. Biol. Med., 40, 54-62. DOI: 10.1016/j.freeradbiomed.2005.08.011

Guichardant, M., Lagarde, M. (2009). Analysis of biomarkers from lipid peroxidation: a comparative study. Eur. J. Lipid Sci. Techn., 111(1), 75-82. DOI: 10.1002/ ejlt.200800069

Halliwell, B., Gutteridge, J. M. C. (1984). Oxygen-Toxicity, Oxygen Radicals, Transition-Metals and Disease. Biochem J., 219(1), 1-14.

Ji, R. R., Befort, K., Brenner, C. J., Woolf, C. J. (2002). ERK MAP kinase activation in superficial spinal cord neurons induces prodynorphin and NK-1 upregulation and contributes to persistent inflammatory pain hypersensitivity. J. Neurosci., 22, 478-485. DOI: 10.1371/journal. pone. 0087788

Kimura, A., Naka, T., Muta, T., Takeuchi, O., Akira, S., Kawase, I., Kishimot, T. (2005). Suppressor of cytokine signaling-1 selectively inhibits LPS-induced IL-6 production by regulating JAK-STAT. Proc. Natl. Acad. Sci. USA, 102, 17089-17094. DOI: 10.1073/ pnas.0508517102

Laguerre, M., Lecomte, J., Villeneuve, P. (2007). Evaluation of the ability of antioxidants to counteract lipid oxidation: existing methods, new trends and challenges.
Prog. Lipid Res., 46(5), 244-282. DOI: 10.1016/j. plipres.2007.05.002

Leger, C. L. (2006). Anti-oxidants d'origine alimentaire: diversité, modes d'action anti-oxydante, interactions. OCL, 13, 1, 59-69. DOI: 10.1051/ocl.2006.0059

Lee, D., Ezhkova, E., Li, B., Pattenden, S. G., Tansey, W. P., Workman, J. L. (2005). The proteasome regulatory particle alters the SAGA coactivator to enhance its interactions with transcriptional activators. Cell, 123(3), 423-436.

Massarenti, P., Biasi, F., De Francesco, A., Pauletto, D., Rocca, G., Silli, B., ..., Palmo, A. (2004). 4-Hydroxynonenal is markedly higher in patients on a standard long-term home parental nutrition. Free Rad. Res., 38, 73-80. DOI: 10.1080/10715760310001636346

Miller, J. K., Brzezinska-Slebodzinska, E., Madsen, F. C. (1993). Oxidative stress, antioxidants, and animal function. J. Dairy Sci., 76(9), 2812-2823. DOI: 10.3168/jds. s0022-0302(93)77620-1

Miller, E. R., Pastor-Barriuso, R., Dalal, D., Riemersma, R. A., Appel, L. J., Guallar, E. (2005). Meta-analysis: High-dosage vitamin E supplementation may increase all-cause mortality. Ann. Intern. Med., 142(1), 37-46. DOI: 10.1016/j.accreview.2005.04.017

Montine, K. S., Olson, S. J., Amarnath, V., Whetsell, J. R. W. O., Graham, D. G., Montine, T. J. (1997). Immunohistochemical detection of 4-hydroxy-2-nonenal ad-ducts in Alzheimer's disease is associated with inheritance of APOE4. Am. J. Pathol., 150, 437-443.

Munasinghe, D. M. S., Ichimaru, K. I., Matsui, T., Sugamoto, K., Sakai, T. (2003a). Lipid peroxidation-derived cytotoxic aldehyde, 4-hydroxy-2-nonenal in smoked pork. Meat Sci., 63(3), 377-380. DOI: 10.1016/s03091740(02)00096-7

Munasinghe, D. M. S., Ichimaru, K. I., Ryuno, M., Ueki, N., Matsui, T., Sugamoto, ..., Sakai, T. (2003b). Lipid peroxidation-derived hepatotoxic aldehydes, 4-hydroxy-2ehexenal in smoked fish meat products. Fisher. Sci., 69(1), 189-194. DOI: 10.1046/j.1444-2906.2003.00605.x

Munasinghe, D. M. S., Ohkubo, T., Sakai, T. (2005). The lipid peroxidation induced changes of protein in refrigerated yellowtail minced meat. Fisher. Sci., 71(2), 462-464. DOI: 10.1111/j.1444-2906.2005.00987.x

Munasinghe, D. M. S., Kawahara, S., Sakai, T. (2006). Effects of $\mathrm{NaCl}$ on 4-hydroxy-2-hexenal formation in yellowtail meat stored at $0^{\circ} \mathrm{C}$. Biosci. Biotechnol Biochem., 70(12), 3036-3038. DOI: 10.1271/bbb.60275

Niki, E. (2009). Lipid peroxidation: physiological levels and dual biological effects. Free Radic. Biol. Med., 47(5), 469-484. DOI: 10.1016/j.freeradbiomed.2009.05.032 
Pedersen, L. B., Murray, T., Popham, D. L., Setlow, P. (1998). Characterization of dacC, which encodes a new low-molecular-weight penicillin-binding protein in $\mathrm{Ba}$ cillus subtilis. J. Bacteriol., 180(18), 4967-4973.

Poggioli, S., Mary, J., Bakala, H., Friguet, B. (2004). Evidence of preferential protein targets for age-related modifications in peripheral blood lymphocytes. Ann. New York Acad. Sci., 1019, 211-214. DOI: 10.1196/annals. 1297.034

Poli, G., Schaur, R. J., Siems, W. G., Leonarduzzi, G. (2008). 4-Hydroxynonenal: a membrane lipid oxidation product of medicinal interest. Med. Res. Rev., 28(4), 569-631. DOI: $10.1002 /$ med.20117

Pré, J. (1991). Lipid-peroxidation. Pathol. Biol., 39(7), $716-736$

Sakai, T., Kawahara, S. (2009). Lipid peroxidation-derived toxic aldehyde, 4-hydroxynonenal contents in roast pork of some chinese restaurants in Miyazaki. Bull. Facult. Agric. Miyazaki Univ., 55.

Sangvanich, P., Mackness, B., Gaskell, S. J., Durrington, P., Mackness, M. (2003). The effect of high-density lipoproteins on the formation of lipid/protein conjugates during in vitrooxidation of low-density lipoprotein. Biochem. Biophys. Res. Com., 300, 501-506. DOI: 10.1016/s0006-291x(02)02849-8

Schacky, C., Harris, W. S. (2007). Cardiovascular benefits of omega-3 fatty acids. Cardiovasc. Res., 73(2), 310-315. DOI: 10.1016/j.cardiores.2006.08.019

Simopoulos, A. P. (2008). The importance of the omega-6/ omega-3 fatty acids ratio in cardiovascular disease and other chronic diseases. Exp. Biol. Med., 233(6), 674-688. DOI: 10.3181/0711-mr-311

Spears, J. W., Weiss, W. P. (2008). Role of antioxidants and trace elements in health and immunity of transition. Dairy Cow. Vet. J., 176(1), 70-76. DOI: 10.1016/j. tvj1.2007.12.015
Uchida, T., Yamaguchi, Y., Matsuyama, Y., Honjo, T. (1995). The red-tide dinoflagellate Heterocapsa sp. kills Gyrodinium instriatum by cell contact. Mar. Ecol. Prog. Ser., 118, 301-303. DOI: 10.3354/meps118301

Uchida, N., Buck, D. W., He, D., Reitsma, M. J., Masek, M., Phan, T. V. (2000). Direct isolation of human central nervous system stem cells. Proc. Natl. Acad. Sci. USA, 97, 14720-14725. DOI: 10.1073/pnas.97.26.14720

Uchida, S., Sasaki, S., Furukawa, T., Hiraoka, M., Imai, T., Hirata, Y., Marumo, F. (1993). Molecular cloning of a choride channel that is regulated by dehydration and expressed predominantly in kidney medulla. J. Biol. Chem., 268, 3821-3824.

Zanardi, E., Dorigoni, V., Badiani, A., Chizzolini, R. (2002). Lipid and colour stability of Milano-type sausages: effect of packing conditions. Meat Sci., 61, 7-14. DOI: 10.1016/s0309-1740(01)00152-8

Zarkovic, N. (2003). 4-hydroxynonenal as a bioactive marker of pathophysiological processes. Mol. Aspec. Med., 24(4-5), 281-291. DOI: 10.1016/s0098-2997(03) 00023-2

Van Acker, S., Van Balen, G. P., Van Den Berg D. J., Bast, A., Van Der Vijgh, W. J. F. (1998). Influence of iron chelation on the antioxidant activity of flavonoids. Biochem. Pharmacol., 56(8), 935-943. DOI: 10.1016/ s0006-2952(98)00102-6

Vertuani, S., Angusti, A., Manfredini, S. (2004). The antioxidants and pro-antioxidants network: an overview. Curr. Pharm. Des., 10(14), 1677-1694. DOI: $10.2174 / 1381612043384655$

Winterbourn, C. (2008). Reconciling the chemistry and biology of reactive oxygen species. Nat. Chem. Biol., 4(5), 278-286. DOI: 10.1038/nchembio.85 